\title{
THE EFFECT OF SOILAGGREGATE SIZE AND P DOSAGE ON AMF SPORES NUMBER IN SHORGUM (Sorghum bicolor L.)
}

\author{
Samsu $^{\text {I) }}$,Henry N Barus ${ }^{2}$, Uswah Hasanah $^{2)}$ \\ 1) Agrotechnology Faculty of Agriculture, Tadulako University \\ ${ }^{2}$ Faculty of Agriculture, Tadulako University Email: ollenk_samsu@yahoo.co.id, \\ henbarus@hotmail.com,uswahmugni@yahoo.co.id
}

\begin{abstract}
Mycorrhiza is a biological agent to help fertility of soil and plants. Application of mycorrhiza on the land in the form of inoculum is often used in agricultural land in the name of quality of inoculum that also influenced by the content of existing spores. One of them is growing medium. This study aimed to study the effect of soil aggregate size and P dosage on the number of mycorrhizal spores in sorghum plants. The research design used was Randomized Block Design consisting of 2 factors. First factor was soil aggregate size $(\mu \mathrm{m})$ which consisted of 4 treatments: U1 $=<2000, \mathrm{U} 2=500-1000, \mathrm{U} 3=200-500, \mathrm{U} 4=<200$, and second factor was P dosage: 100 $\mathrm{mg} / \mathrm{kg}$ and $300 \mathrm{mg} / \mathrm{kg}$. Each treatment combination was repeated 3 times so that there were 24 units of experimental unit. Observation parameters included the percentage of the infected root, number of spores, plant height and dry weight of the plant. The research was conducted in Greenhouse and Agronomy Laboratory of Agricultural Faculty of Tadulako University Palu. The various sizes of soil aggregates do not affect the amount of arbuscular mycorrhizal spores in sorghum plants. P 100 $\mathrm{mg} / \mathrm{kg}$ or $\mathrm{f} \mathrm{P} 300 \mathrm{mg} / \mathrm{kg}$ dosage used do not address the effect of the mycorrhizal spores. There is no interaction between soil aggregate size and $\mathrm{P}$ dosage to the amount of mycorrhizal spores in sorghum plants.
\end{abstract}

Keywords: Number Of Mycorrhizal Spores, P Dosage, Soil Aggregate Size, Sorghum.

\section{INTRODUCTION}

Arbuscular mycorrhizal fungi (FMA) is a mutual symbiotic fungi with plant roots. Mycorrhizal fungi contribute to expand the absorption area of the root, so that the absorption of nutrients, especially $\mathrm{P}$ becomes better (Kabirun, 2004). Utilization of mycorrhiza gives several advantages, among others: in agroecosystem microzia will help the absorption of nutrients and water through the expansion of the roots, and improve the efficiency of phosphate fertilizer (Sastrahidayat, 2011). Mycorrhizal fungi can also produce growth regulator hormones such as cytokines and gibberellins and can improve phosphate metabolism. Increased nutrient uptake and growth dueto mycorrhizal applications hence increased yield of crop production (Kabirun, 2004).
FMA also obtained food among others carbohydrates from the host plant (Husin, 2000). FMA can be used as one of the technology in helping the enchancment of plant nutrient fertilization efficeincy. Based on the research (Moelyohadi et al., 2012).

The use of FMA as a biological agent in some types of plants is now getting a lot of attention. This is not only because of its ability to symbiotize with various types of plants, but also the main thing is FMA can help the plant in improving the efficiency of nutrient absorption

The role of FMA is very important in terms of nutrient cycles conservation, helping to improve soil structure, carbon transport in root systems, overcoming the degradation of soil fertility and protecting plants from disease, as well as 
phytoremediation agents (Jeffries et al., 2003).

FMA products in the form of inoculums are generally spores of a particular species or mixture of more than one FMA species. The resulting spores and mycelia are mixed with a carrier which is generally a clay or zeolite mineral (Nurbaity et al., 2009). One of the obstacles to not yet widespread use of FMA technology in the community is the limited availability of FMA inoculants produced in a large scale or commercially.

The availability of inoculums in good quantity and quality is an important factor in the use of FMA on a wider scale. One of the effort in improving the quality of mycorrhizal spores inoculum is to increase the number of spores per unit of mass, generally inoculum media used is the soil and not the soil, among others, ziolite. There are several factors that influence the development of spores in the soil, among others, growing media (soil), host plants, temperature, light and moisture.

This study focus was to observe the correlation of physical properties or the size of soil aggregates to the development of mycorrhizal spores, the study or information about this is still very rare or limited incorrectly stated about. Small soil aggregate sizes are unfavorable if used in the long term because it potentially increase the volume of water held so that it stunt sporulation of FMA (Smith and Read, 2008).

As for the soil chemical properties studied in this study is the relationship between the $\mathrm{P}$ concentration with the development of the number of spores. The increase in the number of mycorrhizae is due to the increased effectiveness of mycorrhizae in the rooted areas that are accelerated under P-deficiency. The statements above are in accordance with the experiments performed (Mosse, 1981) proving that low $\mathrm{P}$ availability increases mycorrhizal growth in root areas and increases mycorrhizal effectiveness in providing $\mathrm{P}$ for plants. The availability of sufficient $\mathrm{P}$ in the root area will actually decrease the number of mycorrhizas as a result of the inhibition of mycorrhizal growth at $\mathrm{P}$ conditions available which is quite high (Pratikno et al., 2002).

Sorghum (Sorghum bicolor L.) is selected as an indicator plant because of its good rooting system for mycorrhizal formation by forming more secondary roots; in addition, sorghum is a food crop of carbohydrate sources that are relatively resistant to drought and inundation and can grow almost in every type of land (Laimeheriwa, 1990).

So far, there isstill little information about the effect of soil aggregate size on FMA inoculant production. Based on the description above it is necessary to test the provision of low doses and various sizes of soil aggregates to the number of spores

\section{RESEARCH METHODS}

The study was conducted in a greenhouse. and Agronomy Laboratory of Agricultural Faculty of Tadulako University of Palu, from September 2015 to December 2015.

The tools used in this research were pot, oven, knife / cutter, measuring cylinder, microscope, scales, centrifuge, centrifuge, spore nippers, petri dish, filter paper, object glass, bar, spray pumpkin, $2000 \mu \mathrm{m}, 1000$ $\mu \mathrm{m}, 500 \mu \mathrm{m}, 200 \mu \mathrm{m}, 125 \mu \mathrm{m}, 63 \mu \mathrm{m}$, and $20 \mu \mathrm{m}$,

The materials used in this study were sterile soil, sorghum seeds, Inokulan FMA (mixed) processed by LIPI Bogor (Biovam), Trypan blue, $\mathrm{KOH} 10 \%, \mathrm{HCl} 1 \%, \mathrm{~N}$ (NH4NO3), $\mathrm{K}$ ( $\mathrm{KCl}), \mathrm{Mg}$ ( $\mathrm{MgSO} 4)$, $\mathrm{Zn}$ (ZnSO4), $\mathrm{Cu}$ (CuSO4), P (KH2PO4), PVLG and Glycerin.

This study used a randomized block design (RAK) consisting of 2 factors. The first factor of aggregate size $(\mu \mathrm{m})$ consisted of 4 treatments: $\mathrm{U} 1=2000, \mathrm{U} 2=1000, \mathrm{U} 3$ $=500, \mathrm{U} 4=200$, and the second factor was the P dose: $100 \mathrm{mg} / \mathrm{kg}$ and $300 \mathrm{mg} /$ $\mathrm{kg}$. Each treatment combination was repeated 3 times so that there were 24 experimental units. 


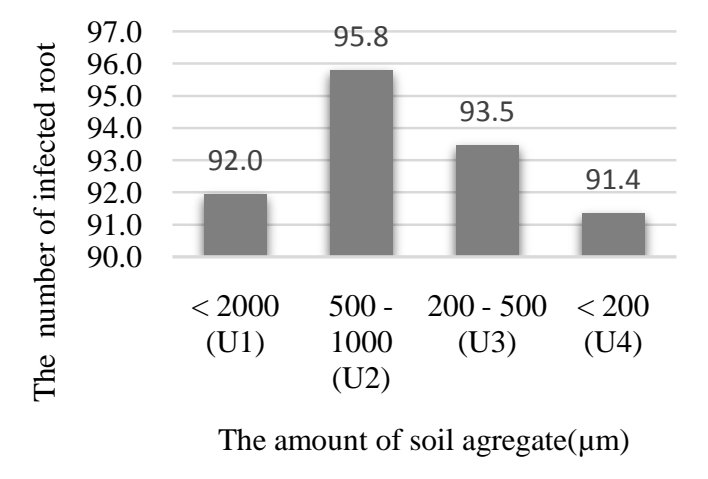

Figure 1. Average of the number of roots infected by mycorrhiza.

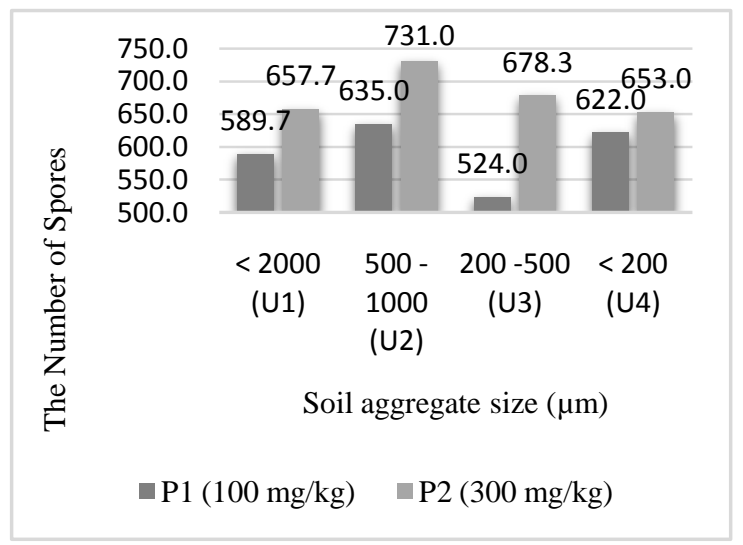

Figure 2. Average of the number of mycorrhiza spore at different $\mathrm{P}$ dosage.

\section{RESULTS AND DISCUSSION}

Percentage of Infected Root. Variance analysis showed that both single and intercultural treatments (soil aggregate size and $\mathrm{P}$ dose) had no significant effect on sorghum root infection. There was a tendency of aggregate size of $1000(\mu \mathrm{m})$ to show higher root percentage of traction than smaller soil aggregate size, as shown in Figure 1.

The treatment of soil aggregate size $1000(\mu \mathrm{m})$ showed that there were more infected roots with the percentage 98 . $5 \%$ compared to the others, In soil conditions the softer ground strength will increase so that it becomes a barrier to root growth. So that larger aggregate sizes have more infections, it would be that the intestinal infections of FMA roots are influenced by fertilization, pesticides, light intensity, season, soil moisture and plant susceptibility (Fakuara, 1988). and also the intensity of the sun and temperature are very influential on the percentage of infected root of FMA on the roots of sorghum plants, Mycorrhizae produces braided hypha and infects the roots to increase the capacity of plants to absorb nutrients and water (Djaya, 2003).

Number of Spores.Variance analysis showed that both single and intercated treatments (the size of the soil aggregate and the $\mathrm{P}$ dose) had no significant effect on the number of spores. The number of spores formed in each treatment combination was presented in Figure 2.

The picture above shows that the soil aggregate size did not provide significant results with the number of mycorrhizal spores, but from the amount of 50 / $5 \mathrm{~g}$ of mycorrhizal spores of soil originating from.

Lipi Bogor which was tested for \pm 2 months on campus soil (around academic garden) to sorghum plant, there was amount of $600 / 5 \mathrm{~g}$ of mycorrhizal spores, this shows an increase of $12 \times$ lip spores \pm 2 months. The formation of spores in soil aggregate size media can be attributed to optimal aeration, good drainage and oxygen supply (Saif 1981).

There are two factors: biotic and abiotic. Biotic factors that play a role include fungi species, host plant species, and symbiotic bacterial species with mycorrhizal fungi. Abiotic factors that play a role include media composition, water content, $\mathrm{pH}$, air humidity, light intensity and inoculum production method (Nusantara et al., 2008).

Plant Height. Varianc analysis showed that soil aggregate size treatment had a very significant effect on the height of sorghum plant during 9th MST observation. MST Nutrient distribution gave a significant effect on the height of sorghum plant. No treatment interactions (soil aggregate size and $\mathrm{P}$ dose) were presented in Figure 3. 


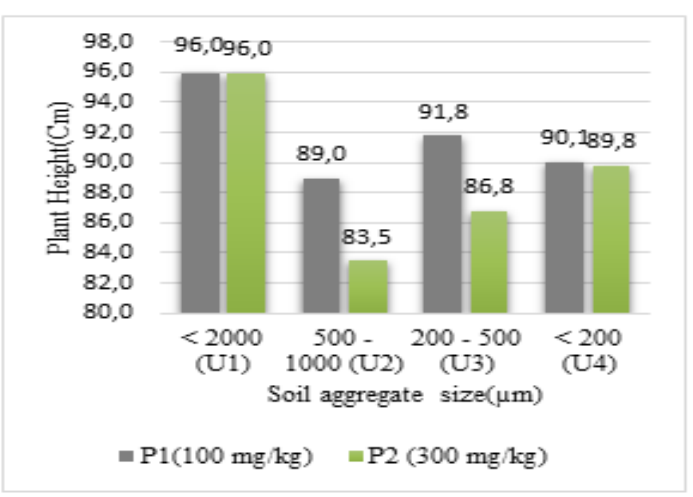

Figure 3. The average of plant height at 9 MST

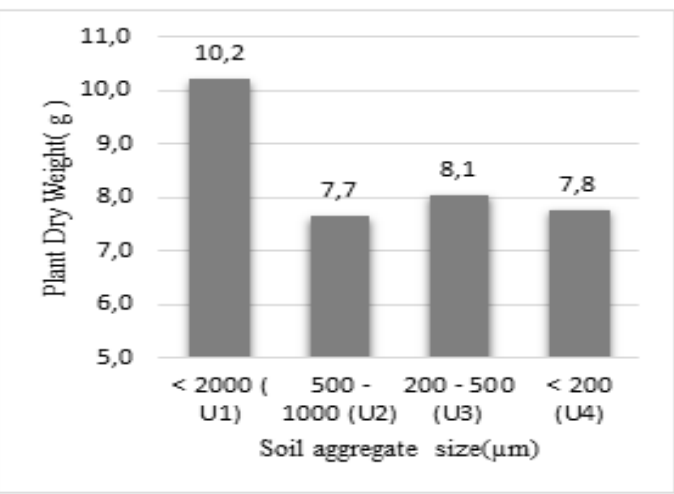

Figure 4 . The average of plant height

Table 1, The average of plant height

\begin{tabular}{ccccc}
\hline Treatment & \multicolumn{4}{l}{ Plant Height 9 MST } \\
& \multicolumn{4}{l}{} \\
\cline { 2 - 5 } & U1 & U2 & U3 & U4 \\
P1 & 96.0 & 89.0 & 91.8 & 90.1 \\
Pverage & 96.0 & 83.5 & 86.3 & 89.8 \\
\hline BNJ 5\% & $86.3 \mathrm{a}$ & $89.1 \mathrm{a}$ & $90.0 \mathrm{ab}$ \\
\hline
\end{tabular}

Information: The value followed by the same letter in the same column is not different at the BNJ test level of 0.5 or $5 \%$.

The soil aggregate size treatment of $2000(\mu \mathrm{m})$ in sorghum gave the highest plant height compared to other sizes, the larger aggregate size had the highest value of $96 \mathrm{~cm}$, the difference in soil aggregate size that indirectly affected the growth and yield of the crop due to its effects on porosity, the availability of groundwater and soil resistance to root movement in the soil (Alexander and Miller, 1991).

Treatment of soil aggregate size $2000(\mu \mathrm{m}), 1000(\mu \mathrm{m}), 500(\mu \mathrm{m})$ gave the highest plant height at $\mathrm{P} 100 \mathrm{mg} / \mathrm{kg}$ dosage compared with P $300 \mathrm{mg} / \mathrm{kg}$ dosage.

Result of $5 \%$ BNJ test (Table 3), Treatment of 2000 ( $\mu \mathrm{m}$ soil aggregate), showed the highest plant height and did not significantly different with aggregate size $1000(\mu \mathrm{m})$ but significantly different with $500(\mu \mathrm{m})$ and $200(\mu \mathrm{m})$.

Braunack (1995) found that germination of corn and soybeans were faster and larger when planted in aggregates of 1-2 mm compared with the rougher aggregates (5-15 $\mathrm{mm})$.

Plant Dry Weight. Variance analysis showed that both single and intercated treatments (the size of the soil aggregate and the dose) had no significant effect on the dry weight of the plant. There was a tendency for the size of aggregate $2000(\mu \mathrm{m})$ to show more weight than the smaller particle size, presented in Figure 4.

At figure above it shows that larger aggregate soils indicate greater dry weight due to the growth process in soil aggregate $2000(\mu \mathrm{m})$ better than small soil particle size, since the soil was $2000(\mu \mathrm{m})$ better thanand the small pore space is better so that the planting root is easy to penetrate the soil and facilitate the plant grow well.

Although the effect of soil aggregate size was not seen in this study, to increase the spores (FMA), but on the dry weight parameter of plants there was a tendency that larger aggregate soil sizes give better weight in comparison with others.

Plant growth on larger soil aggregate size, where oxygen availability makes respiration process better, so root development will be easier to develop so that the metabolic process in producing plant biomass.

Although the effect of soil aggregate size is not seen in this study, sprouting 
FMA spores by using sorghum plants and campus soil (around academic gardens) was capable to produce the number of spores until twelve-fold. This indicates that the administration of the $\mathrm{P}$ element is highly responded by FMA spores, the soil used very poor with macro and micro nutrients.

\section{CONCLUSIONAND SUGGESTION}

Conclusion. Based on the results of the research that has been done it can be concluded that:
The various sizes of soil aggregates do not affect the amount of spores of arbu scular mycorrhizal fungi in sorghum plants.

P $100 \mathrm{mg} / \mathrm{kg}$ or P $300 \mathrm{mg} / \mathrm{kgdosage}$ used do not address the effects of the mycorrhizal spores.

There is no interaction between soil aggregate size and $\mathrm{P}$ dosage to the amount of mycorrhizal spores in sorghum plants.

Suggestion. Sorghum plants and campus land (academic garden faculty of agriculture untad) suitable in use to increase the number of spores. besides generating a FMA inoculum rich in mycorrhizal spores.

\section{BIBLIOGRAPHY}

Alexander dan Miller, 1991.The Effect of Soil Aggregate Size on Early Growth And Shoot-Root Ratio Of Maize (Zea mays L.). Plant and Soil 138 (189-194)

Braunack, M.V. 1995. Effect of Aggregate Size and Soil Water Content on Emergence of Soybean (Glycine max L. Merr.) and Maize (Zea mays L.).Soil Tillage Res. 33:149-161.

Djaya, A.A. 2003. Mikoriza. Laporan Kegiatan Pendidikan Non Gelar. Fakultas Pertanian. Universitas Palangkaraya, Palangkaraya.

Fakuara, M.Y. 1988. Mikoriza, Teoridan Kegunaan dalam Praktek. Pusat Antar Universitas Institut Pertanian Bogor. Hal 19-46.

Husin, E.F. 2000.Cendawan Mikoriza Arbuskula. Fakultas Pertanian Universitas Andalas: Padang

Jeffries, P., Gianinazzi, S., Perotto, S., Tuman, K., dan Barea, J. (2003).The Contributionof Arbuscular Mycorrhizal Fungi inSustainable Maintenance of Plant Health and Soil Fertility.J. Biology dan Fertility of Soils 37: 1-16.

Kabirun, S. 2004. Peranan Mikoriza Arbuskula Pada Pertanian Berkelanjutan. Pidato Pengukuhan Jabatan Guru Besar dalam Mikro biologi pada Fakultas Pertanian Universitas Gadjah Mada.

Laimeheriwa, L. 1990. Teknologi Budidaya Sorgum. Departemen Pertanian Balai Informasi Pertanian Propinsi Irian Jaya.

Moelyohadi Y, MU Harun, Munandar, R Hayati, dan N Gofar 2012. Pemanfaatan Berbagai Jenis Pupuk Hayati pada Budidaya Tanaman Jagung (Zea mays L.) Efisien Hara di Lahan Kering Marginal.J Lahan Suboptimal 1(1): 31-39.

Mosse, B. 1981.Vesicular mycorrhyza research for tropical agriculture.Rer Bull, 94. Hawaii Inst. Of Trop. Agric and human resources.Univ of Hawaii, Honolulu.

Nurbaity, A., Herdiyantoro, D., dan Mulyani, O. 2009. Pemanfaatan Bahan Organik sebagai Bahan Pembawa Inokulan Fungi Mikoriza Arbuskula.Jurnal Biologi XIII (1) : 17- 11. 
Nusantara, A.D., Kusmana, C., Mansur, I., Darusman, L.K. dan Soedarmadi. 2007. Produksi Spora Glomus etunicatum Berbasis Bahan Alami. JIPI Edisi Khusus 3: 285-294.

Pratikno, H; Syekhfani, Y; Nuraini dan Eko, H. 2002. Pemanfaatan Biomasa Flora Untuk Meningkatkan Ketersediaan dan Serapan P Pada Tanah Berkapur di DAS Brantas Hulu Malang Selatan. Biosain 2(1): 78-91.

Saif SR 1981. The influence of soil aeration on the efficiency of vesicular-arbuscular mycorrhizae. I. Effect of soil oxygen on the growth and mineral uptake of Eupatorium odoratum L. inoculated with Glomus macrocarpus. New Phytologist 88: 649-659.

Sastrahidayat, I.R. 2011.RekayasaPupukHayatiMikorizaDalamMeningkatkanProduksiPertanian. UB Press. Malang.

Smith, S.E. dan Read, D.J. 2008.Mycorrhizal Symbiosis.3rd ed. Academic Press. San Diego, USA 